\title{
LOW COST ELECTROCHEMICAL SENSORS FOR SILVER, CHLORIDE, BROMIDE AND IODIDE IONS
}

\author{
Raja Ram Pradhananga* and Armila Rajbhandari(Nyachhyon)* \\ *Central Department of Chemistry, Tribhuvan University, Kirtipur, Kathmandu, Nepal.
}

\begin{abstract}
Low cost all solid state pressed pellet $\mathrm{Ag}^{+}$, halides and sulphide sensitive electrodes based on silver sulphide were fabricated. The electrodes have been tested and results compare favorably with commercial electrodes. Pure $\mathrm{Ag}_{2} \mathrm{~S}$ electrode with internal silver metal contact was found to follow Nernstian equation from $1 \times 10^{-1}$ to $1 \times 10^{-5} \mathrm{M}$ of silver ion with slope equal to $59.8 \mathrm{mV}$ per decade change in concentration of $\mathrm{Ag}^{+}$- ion. Electrodes fabricated from equimolar mixture of $\mathrm{Ag}_{2} \mathrm{~S}$ and $\mathrm{Ag}$ halide was found to be sensitive to the respective halide and silver ions. Iodide ion selective electrode prepared from a equimolar mixture of $\mathrm{Ag}_{2} \mathrm{~S}$ and $\mathrm{AgI}$ was found to be selective to iodide ion with negligible interference from bromide and chloride ions. The potentiometric selectivity coefficient $\mathrm{K}_{\mathrm{I}}^{\mathrm{pot}}$,, $\mathrm{K}^{\mathrm{pot}}{ }_{\mathrm{I} \text {.Cl }}$ were found to be $1.77 \times 10^{-2}$ and $7.94 \times 10^{-3}$ respectively. All these electrodes were found to be selective to $\mathrm{Ag}^{+}$ion with negligible interference with $\mathrm{K}_{\mathrm{Ag}, \mathrm{Hg}}^{\mathrm{pot}}$ equal to $1 \times 10^{-5} \mathrm{Hg}^{++}$ion with selectivity coefficient.
\end{abstract}

Keywords: Ion selective electrodes; Potentiometric selectivity coefficient; Silver sulphide.

\section{INTRODUCTION}

Ion selective electrodes (ISEs) have been increasingly used in the determination of concentration of ions in varieties of fields like environmental science, life science, clinical, diagnostic, pharmaceutical, , and water chemistry and so on. The wide spread use of this electro-analytical technique is due to ease of operation, least interference in the analysis and low cost of the instrumentation. Ion selective membrane electrode is the most important part of this analytical technique. A number of ion selective electrodes selective to different ions are now commercially available but they are too expensive for the teaching institute of developing countries like Nepal who can not afford to procure such electrodes for their educational purpose. This greatly hindered in the teaching of analysis with ion selective electrode. The method of fabrication of ISE is usually patented and guarded as trade secret. But however, fabrication of workable inorganic precipitate based ISE in the laboratory is not insurmountable task but demand some effort to prepare well behaved ISE. Several authors [1-7] have given prescription for preparing ISE in the laboratory. No doubt the performance of electrodes with respect to Nernstian behavior, response time and detection limit all depends upon the method of fabrication and surface characteristics of the electrode [ 4-7]. In the present paper, we report a very simple and low cost technique of fabrication of all solid-state pressed pellet $\mathrm{Ag}_{2} \mathrm{~S}$ based ion selective electrode for the determination of $\mathrm{Ag}^{+}, \mathrm{Cl}^{-}, \mathrm{Br}, \mathrm{I}-, \mathrm{S}^{=}$ions. The laboratory made ion selective electrodes have been characterized with respect to Nernstian response, response time and selective coefficients. The performances of the laboratory made ISEs are compared with commercial electrodes and results are quite encouraging. The potentiometric selectivity coefficient $\mathrm{K}_{\mathrm{A}, \mathrm{B}}^{\mathrm{pot}}$, an important parameter of ISE, have been determined by mixed solution method following the IUPAC recommendation [8]

\section{EXPERIMENTAL}

\section{Reagents}

All reagents $\left(\mathrm{AgNO}_{3}, \mathrm{KI}, \mathrm{KBr}, \mathrm{KCl}, \mathrm{HgCl}_{2}\right)$ were of analytical grade. All aqueous solutions were prepared in distilled water.

\section{Electrode preparation}

The $\mathrm{Ag}_{2} \mathrm{~S}$ was precipitated by passing hydrogen sulfide gas to silver nitrate solution till complete precipitation. The precipitate obtained was washed thoroughly with hot water then with acetone and dried at $110^{\circ} \mathrm{C}$ for about 6 hours. The precipitate was pulverized in agate mortar. About $1 \mathrm{~g}$ of precipitate was transferred into $\mathrm{KBr}$ die and was evacuated for $5 \mathrm{~min}$ and then pressed under vacuum for 15 min by applying a pressure of $1 \mathrm{GPa}$ ( i-e 10 tons $/ \mathrm{cm}^{2}$ ) in IR pellet making machine. The pellet was removed carefully from the die and silver paste was carefully applied on one side. The pellet was then mounted in a polypropylene tube with the help of Araldite (Cieba-gigy) and back contact was made with silver epoxy conducting paint with silver disk in which a copper wire was soldiered. When Araldite was completely dried, the electrode was polished in an emery paper and finally in a Bolton cloth with diamond paste to a mirror finished.

Halide ion- selective electrodes were prepared by co-precipitation of Ag-halide and $\mathrm{Ag}_{2} \mathrm{~S}$. To a equal molar solution of potassium halide and sodium sulfide excess silver nitrate solution was added till complete precipitation.

$\mathrm{KX}(\mathrm{aq})+\mathrm{Na}_{2} \mathrm{~S}(\mathrm{aq})+3 \mathrm{AgNO}_{3}(\mathrm{aq})=\mathrm{Ag} \mathrm{X}(\mathrm{s})+\mathrm{Ag}_{2} \mathrm{~S}(\mathrm{~s})+$ $\mathrm{KNO}_{3}(\mathrm{aq})+2 \mathrm{NaNO}_{3}(\mathrm{aq})$ 
The precipitate was treated as described above and ion selective electrode was fabricated.

\section{Determination of selectivity coefficients}

The selectivity coefficients were determined using fixed interference method [8]. In this method the potential of cell comprising an ion selective electrode and reference electrode is measured with solutions of constant level of interference ion, $\mathrm{a}_{\mathrm{B}}$ and varying activity of primary ion $\mathrm{a}_{\mathrm{A}}$. The potential values obtained are plotted versus the activity of primary ion. The intersection of an extrapolation of the linear portions of this curve will indicate the value $a_{B}$ which is to be used to calculate $\mathrm{K}_{\mathrm{A}, \mathrm{B}}^{\mathrm{pot}}$.All potentials were measured relative to saturated calomel electrode using Orion ion meter model 290.

\section{RESULTS AND DISCUSSION}

\section{Potentiometric studies}

\section{Response of $\operatorname{Ag}_{2} \mathrm{~S}$-ISE}

The EMF of the cell in $\mathrm{mV}$ with $\mathrm{Ag}_{2} \mathrm{~S}$ membrane electrode coupled with saturated calomel reference electrode is plotted against $-\log \left[\mathrm{Ag}^{+}\right]$which is shown in figure 1.The EMF of the cell follows the following equation.

\section{$\mathrm{E}=606+59.8 \log \left[\mathrm{Ag}^{+}\right]$}

The electrode shows linearity in the EMF vs - $\log \left[\mathrm{Ag}^{+}\right]$plot over concentration range of $10^{-1} \mathrm{M}$ to $10^{-6} \mathrm{M}$.

The $\mathrm{Ag}_{2} \mathrm{~S}$ electrode was also found to be sensitive to the sulphide ion but the change in slope per decade change in sulphide ion concentration was found to be $31.1 \mathrm{mV}$ which was in agreement with the Nernst's equation. The silver sulphide electrode had been successfully used to determine the trace amount of hydrogen sulphide in cigarette smoke which is described elsewhere [4]

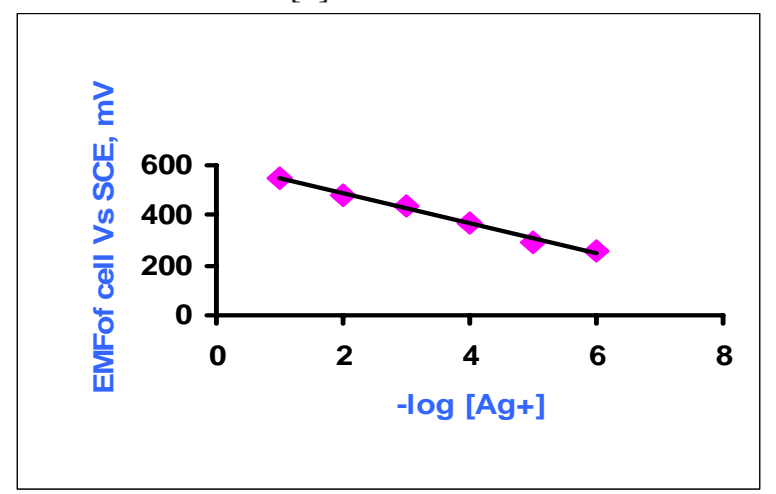

Fig 1: Plot of Cell EMF against -log $\left[\mathrm{Ag}^{+}\right]$

\section{Response of $\operatorname{Ag}_{2} \mathrm{~S}-\mathrm{AgI}$ ISE to I' ion}

The EMF of the cell in $\mathrm{mV}$ with $\mathrm{Ag}_{2} \mathrm{~S}-\mathrm{AgI}$ membrane electrode coupled with saturated calomel reference electrode is plotted against $-\log \left[\mathrm{I}^{-}\right]$which is shown in figure 2.The EMF of the cell found to follows the following equation.

$\mathrm{E}=-339-57.5 \log \left[\mathrm{I}^{-}\right]$

The electrode shows linearity in the EMF vs -log $\left[\mathrm{I}^{-}\right]$plot over concentration range of $10^{-1} \mathrm{M}$ to $10^{-6} \mathrm{M}$ with a slope of $57.5 \mathrm{mV}$ per decade change in concentration of iodide ion at $25^{\circ} \mathrm{C}$. The slope is slightly less than the expected value from Nernst equation but is quite acceptable for a well behaved membrane electrode. The performances of the laboratory made ion selective electrodes are compared with commercial EDTQualiprobe $\mathrm{Ag}^{+}$electrode and Orion 94-16 Model $\mathrm{Ag}^{+}$ion selective electrode. The results are tabulated in table 1 . If we look at the table the performances of the low cost ion selective electrode prepared in the laboratory by simple techniques are comparable to the commercial electrode manufacture by different manufacturers. This is happy situation for developing countries that can not afford to procure expensive commercial electrode but would like to use this powerful technique of analysis.

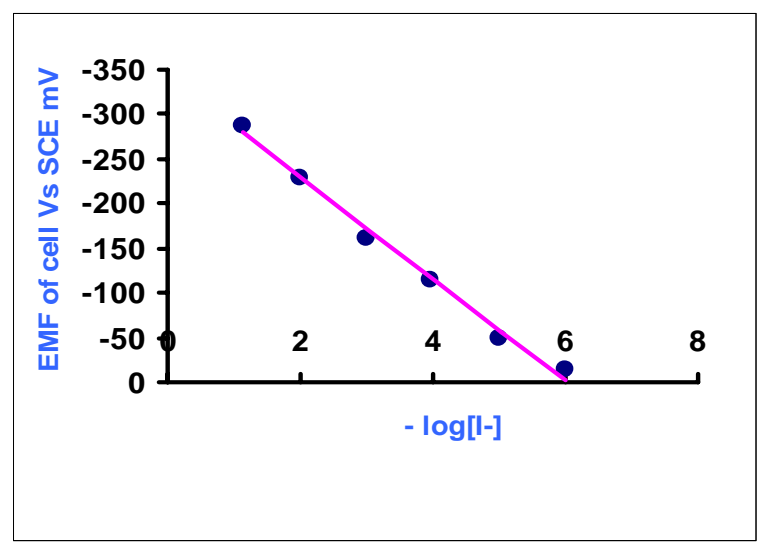

Fig 2: Plot of Cell EMF against - log [I-]

\section{Selectivity co-efficient and potentiometric titration}

Potentiometric selectivity coefficients, $\mathrm{K}_{\mathrm{A}, \mathrm{B}}^{\mathrm{pot}}$ are expressed according to Nickolsky - Eisenmann equation (8)

$\mathrm{E}=\mathrm{E}_{0}+\mathrm{RT} / \mathrm{n}_{\mathrm{A}} \mathrm{F} \ln \left(\mathrm{a}_{\mathrm{A}}+\sum \mathrm{K}_{\mathrm{A}, \mathrm{B}}^{\mathrm{pot}}\left(\mathrm{a}_{\mathrm{B}}\right)^{\mathrm{n}}{ }_{\mathrm{A}} /{ }_{\mathrm{B}}^{\mathrm{n}}\right)$

Where $a_{A}$ and $a_{B}$ are the activities of main and interfering ions having charges $n_{A}$ and $n_{B}$ respectively, $E_{0}$ is standard potential of the electrode and $\mathrm{K}_{\mathrm{A}, \mathrm{B}}^{\mathrm{pot}}$ is the selectivity coefficient which describes the relative sensitivity of determinant ion. In

Table 1: Different constants of ion selective electrode

\begin{tabular}{|l|c|c|c|c|c|}
\hline \multicolumn{1}{|c|}{ Electrode } & Determinant ion & slope $\mathbf{~ m V}$ & Intercept & Linear range & $\begin{array}{c}\text { Coefficient of } \\
\text { determinant }\end{array}$ \\
\hline $\mathrm{Ag}_{2} \mathrm{~S}$ & $\mathrm{Ag}^{+}$ & 59.8 & 606 & $1 \mathrm{X} 10^{-1}-1 \mathrm{X} 10^{-5} \mathrm{M}$ & 0.9933 \\
\hline $\mathrm{Ag}_{2} \mathrm{~S}-\mathrm{AgI}$ & $\mathrm{I}^{-}$ & 57.5 & -339 & $1 \mathrm{X} 10^{-1}-1 \mathrm{X} 10^{-5} \mathrm{M}$ & 0.9865 \\
\hline $\begin{array}{l}\text { EDT- Qualiprobe } \mathrm{Ag}^{+}- \\
\text {electrode }\end{array}$ & $\mathrm{Ag}^{+}$ & 59.5 & 594 & $1 \mathrm{X} 10^{-1}-1 \mathrm{X} 10^{-5} \mathrm{M}$ & 0.9992 \\
\hline $\begin{array}{l}\text { Orion 94-16 Model } \mathrm{Ag}^{+}- \\
\text {electrode }\end{array}$ & $\mathrm{Ag}^{+}$ & 59.0 & 553 & & - \\
{$\left[\begin{array}{l}\text { Ref. 9] } \\
\hline\end{array}\right.$}
\end{tabular}


the present study mixed solution method was used to determine the selectivity of $\mathrm{Ag}_{2} \mathrm{~S}$-AgI electrode containing iodide ion with $\mathrm{Br}^{-}, \mathrm{Cl}^{-}$ions as interfering ions. Following the standard method [8], the selectivity co-efficient was found to be $7.94 \times 10^{-3}$ and $1.77 \times 10^{-2}$ for $\mathrm{Cl}^{-}$and $\mathrm{Br}^{-}$respectively. These show that response of laboratory made $\mathrm{Ag}_{2} \mathrm{~S}$-AgI electrode to I-- was not adversely affected by the presence of bromide and chloride ions. The selectivity coefficient clearly indicates that the laboratory made iodide ion selective electrode can be used to determine the iodide ion concentration by direct potentiometric method even in presence of ten fold excess of bromide or chloride ion as interfering ions. The laboratory made iodide ion selective electrode could be used with usual advantage of ISE as an indicator electrode for potentiometric titration of mixture of chloride, bromide and iodide ions. A typical potentiometric curve for titration of equimolar mixture of chloride, bromide and iodide ions with silver nitrate solution is shown in figure 3 . The curve shows three inflection points as expected for the end points for iodide, bromide and chloride ions respectively. The solubility products of Silver iodide being the least so the first end point correspond to the complete reaction of silver ion with iodide ion. The end point for iodide matches with the stoichiometric end point. This clearly indicated the absence of interference by bromide and chloride in the determination of iodide by potentiometric titration with silver ion. The second end point corresponds to the complete precipitation of bromide as silver bromide. The end point for bromide ion occurred too late compared to the stoichiometric end point producing a positive error. It is a known fact that in the precipitation of bromide ion by silver ion, a coprecipitation of chloride ion takes place. Moreover owing to the similar crystal structures of silver bromide and silver chloride, adsorption of chloride ion on silver bromide is likely to takes place which give rise to the positive error in the titration of bromide ion by silver nitrate solution. The third end point is obviously due to the formation of silver chloride. There was a negative titration error in the third end point which is quite expected as part of the chloride had already been coprecipitated along with silver bromide in the second end point.

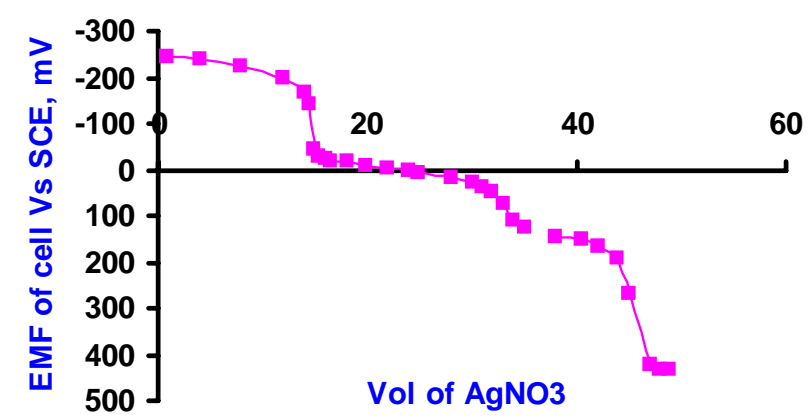

Fig 3: Potentiometric titration of halide mixture with silver nitrate
The $\mathrm{Ag}_{2} \mathrm{~S}$ electrode display very good selectivity for $\mathrm{Ag}^{+}$ion. The interference to the $\mathrm{Hg}^{++}$ion in the determination of silver ion by direct potentiometric method was determined by mixed solution method. The plot of EMF of the cell with $\mathrm{Ag}_{2} \mathrm{~S}$ membrane electrode coupled with saturated calomel reference electrode against $-\log \left[\mathrm{Ag}^{+}\right]$with fixed $\mathrm{Hg}^{++}$interference ion is shown in figure 4.The $\mathrm{K}^{\mathrm{pot}}{ }_{\mathrm{Ag} \text {, Hg }}$ was found to be equal to $1 \times 10^{-5}$. This extremely low value of selectivity coefficient indicated that response of laboratory made electrode for $\mathrm{Ag}^{+}$ion is not at all affected by the presence of $\mathrm{Hg}^{++}$ion.

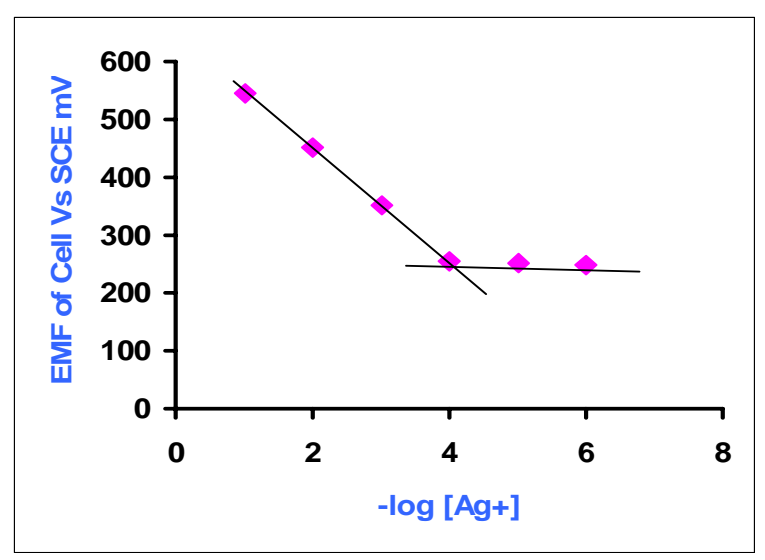

Figure 4: Plot of EMF against -log $\left[\mathrm{Ag}^{+}\right]$(fixed interference $\mathrm{Hg}^{++}$ion)

\section{CONCLUSION}

The laboratory made low cost all solid state silver sulfide based ion selective electrodes respond to $\mathrm{I}^{-}, \mathrm{Br}^{-}, \mathrm{Cl}^{-}$and $\mathrm{Ag}^{+}$ with Nernstian behavior. The performance of these electrodes is in par with the expensive commercial electrodes with respect to the linear range, interference due to the interfering ion and response time.

The electrode can be used for the analysis of halide and mixture of halides by the silver ions by direct potentiometric and potentiometric titration methods. The ease of fabrication, low cost and well behaved nature of the electrodes will certainly play a positive role in the teaching analysis with ion selective electrode. Educational institutes of underdeveloped countries can not afford to procure expensive commercial ion selective electrode for such institutes this home made ion selective electrode is of great value.

\section{ACKNOWLEDGMENT}

One of the authors (Armila Rajbhandari, Nyachhyon) is thankful to Tribhuvan University for granting study leave. The authors are also thankful to Nepal Academy of Science and Technology, Tribhuvan University, Nepal for partial financial support to carry this work. 


\section{REFERENCE}

1. Paspastathopoulos, D.P. and Karayannis, M.I. 1980. Construction and evaluation of solid state iodide selective electrodes. $J$. Chem.Edu. 57 (7): 904.

2. Martin, C.R. and Feiser, H. 1980. Coated-wire ion selective electrodes and their application to the teaching laboratory. J.Chem.Edu. 57 (7): 513

3. Fricke, G.H. and Kuntz, M.J. 1977. Inexpensive solid-state ion selective electrodes for student use. J.Chem.Edu. 54 (8): 517.

4. Tandukar, S. 2001. Determination of hydrogen sulphide in Cigarette smoke by using laboratory made sulphide ion selective electrod., M.Sc dissertation, Central Department of Chemistry, T.U, Kathmandu, Nepal.

5. Yadav, A.P. and Pradhananga, R.R. 1996. Preparation and characterization of silve sulphide/silver iodide ion selective electrodes for the determination of $\mathrm{I}^{-}, \mathrm{S}^{-}$-and $\mathrm{Ag}^{+}$ions. J.Nep. Chem. Soc. 15: 9.
6. Pradhananga, R.R. and Shrestha, L.K 2001. Application of Ag-ion selective electrode for the determination of solubility products of different sparingly soluble silver salts. Anal. Science (Japan). 17: (Supplement) 395-a396.

7. Yadav,A.P. and Pradhananga, R.R. 1994. Analytical study of polycrystalline thick film $\mathrm{Ag}_{2} \mathrm{~S}$ based ion selective electrode. II national conference on Science \& Tech, June 8-11, RONAST, Abs No Chem 8, Kathmandu, Nepal.

8. Umezawa, Y., Buhlmann,P., Umejawa, K., Tohda,K. and Amemiya S.,2000. Potentiometric selectivity coefficients of ion selective electrodes Part I. Inorganic cations. Pure Appl.Chem. 72 (10): 18512082.

9. Hseu,Tong-Ming and Rechnitz, G.A. Rechnitz 1968 . Analytical study of a sulphide ion selective membrane electrodes in alkaline solution. Anal. Chem. 40 (7): 1059. 